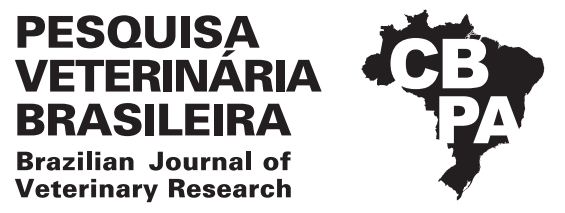

Pesq. Vet. Bras. 39(3):186-191, March 2019 DOI: 10.1590/1678-5150-PVB-5624

Original Article

ISSN 0100-736X (Print)

ISSN 1678-5150 (Online)

\title{
Protein-to-creatinine urinary in the early diagnosis of renal injury in canine pyometra ${ }^{1}$
}

\author{
Marcos C. Sant'Anna², Guilherme F. Martins ${ }^{3}$, Karina K.M.C. Flaiban ${ }^{4}$, \\ Luiz G.C. Trautwein ${ }^{2}$ and Maria I.M. Martins ${ }^{2 *}$
}

\begin{abstract}
Sant'Anna M.C., Martins G.F., Flaiban K.K.M.C., Trautwein L.G.C. \& Martins M.I.M. 2019. Protein-to-creatinine urinary in the early diagnosis of renal injury in canine pyometra. Pesquisa Veterinária Brasileira 39(3):186-191. Departamento de Clínicas Veterinárias, Universidade Estadual de Londrina, Rodovia Celso Garcia Cid, Londrina, PR 86061-900, Brazil.E-mail: imartins@uel.br

Kidney disease that affects bitches with pyometra may lead patients to develop chronic renal failure even after pyometra treatment. Therefore, several studies have sought to clarify the gaps in the understanding of the pathogenesis of renal injury in pyometra. Identification of early detection markers for renal damage, which can predict and identify the prognosis of the disease, is very important. Proteinuria analysis can diagnose kidney damage, since proteins such as albumin are not filtered through the glomerulus and those that undergo glomerular filtration are almost completely reabsorbed by tubular cells. The objective of this study was to evaluate whether the urinary protein-to-creatinine ratio (UPC) can detect renal injury in bitches with pyometra before development of azotemia. For this, 44 bitches with pyometra were divided into two groups: bitches with azotemic piometra $(A, n=15$, creatinine >1.7) and bitches with non-azotemic pyometra (NA, $n=29$ ). The two groups were compared to the control group (CG, $n=12$ ), which had no signs of systemic disease. All animals underwent blood and urine tests. Leukocytosis was more evident in bitches in the A group than in the other groups. This shows that the inflammatory response may be associated with the pathogenesis of renal injury. The median UPC in bitches with pyometra was significantly higher than in the CG, with a median above the reference values. In conclusion, the UPC can be used in bitches with pyometra to detect renal damage before the development of azotemia. It has been suggested that the UPC of bitches with pyometra should be followed through during the postoperative period so that permanent renal lesions secondary to pyometra can be diagnosed and treated properly before the development of azotemia.
\end{abstract}

INDEX TERMS: Protein, creatinine, urinary, renal injury, canine pyometra, UPC, cystic endometrial hyperplasia, proteinuria, bitches, dogs, surgery.

RESUMO.- [Relação proteína-creatinina-urinária no diagnóstico precoce de lesão renal em cadelas com piometra.] A doença renal que afeta cadelas com piometra pode levar a insuficiência renal crônica mesmo após o tratamento. Portanto, vários estudos procuraram esclarecer

\footnotetext{
${ }^{1}$ Received on August 29, 2018.

Accepted for publication on October 22, 2018

${ }^{2}$ Departamento de Clínicas Veterinárias, Universidade Estadual de Londrina (UEL), Rodovia Celso Garcia PR-445 Km 380, Campus Universitário, Londrina, PR, 86061-900, Brazil. *Corresponding author: imartins@uel.br

${ }^{3}$ Hospital Veterinário, Universidade Filadélfia (UniFil), Av. Juscelino Kubitschek 1626, Londrina, PR 86055-585.

${ }^{4}$ Departamento de Medicina Veterinária Preventiva, Universidade Estadual de Londrina (UEL), Rodovia Celso Garcia PR-445 Km 380, Campus Universitário, Londrina, PR 86061-900.
}

as lacunas na compreensão da patogênese da lesão renal na piometra. A identificação de marcadores de lesão renal precoce, que podem prever e identificar o prognóstico da doença é muito importante. A análise da proteinúria pode diagnosticar lesão renal, uma vez que proteínas como a albumina não são filtradas através do glomérulo e aquelas que sofrem filtração glomerular são quase completamente reabsorvidas pelas células tubulares. 0 objetivo deste estudo foi avaliar se a relação proteína-creatinina urinária (UPC) pode detectar lesão renal em cadelas com piometra antes do desenvolvimento de azotemia. Para isso, 44 cadelas com piometra foram divididas em dois grupos: cadelas com piometra azotêmica (A, $n=15$, creatinina $>1,7$ ) e cadelas com piometra não azotêmica ( $N A, n=29)$. Os dois grupos foram comparados 
ao grupo controle (CG, $\mathrm{n}=12$ ), que não apresentaram sinais de doença sistêmica. Todos os animais foram submetidos a exames de sangue e urina. A leucocitose foi mais evidente nas cadelas do grupo A do que nos outros grupos. Isso mostra que a resposta inflamatória pode estar associada à patogênese da lesão renal. A mediana da UPC em cadelas com piometra foi significativamente maior que no CG, com uma mediana acima dos valores de referência. Em conclusão, a UPC pode ser usada em cadelas com piometra para detectar lesões renais antes do desenvolvimento de azotemia. Sugeriu-se que a UPC de cadelas com piometra deve ser acompanhada durante 0 pós-operatório, de modo que as lesões renais permanentes secundárias à piometra possam ser diagnosticadas e tratadas adequadamente antes do desenvolvimento de azotemia.

TERMOS DE INDEXAÇÃO: Proteína, creatinina, sistema urinário, lesão renal, cadelas, piometra, UPC, hiperplasia endometrial cística, proteinúria, caninos, cirurgia.

\section{INTRODUCTION}

Canine pyometra mainly affects adult and elderly bitches during diestrus after uterine contamination by bacteria of the vaginal microbiota during estrus. In this period of the estrous cycle, the bacteria find a favorable uterine environment that is affected by cystic endometrial hyperplasia (Hagman 2004, Pretzer 2008, Verstegen et al. 2008). Escherichia coli is the Gram-negative bacteria most frequently isolated, since it has virulence factors that facilitate its adhesion in the endometrium under the influence of progesterone (Hagman \& Kuhn 2002, Bassessar et al. 2013, Hagman 2017).

Renal damage is common in bitches with pyometra, but it is not fully understood yet. The theory that glomerulonephritis occurs secondary to the deposition of immunocomplexes that are formed because of the inflammatory response, which are triggered by the excess of $E$. coli antigens, has been accepted for a long time (Johnston et al. 2001, Fieni 2006). However, with the development of new renal injury markers that have the capacity to identify the affected renal compartment, this pathogenesis has been contested. The hypothesis that has been most accepted in the last decade is that involving glomerular and tubular renal injury, but there is no evidence of glomerulonephritis (Heiene et al. 2007, Maddens et al. 2010, 2011).

Renal insufficiency that developed during pyometra is one of the main prognostic factors of the affection (Kuplulu et al. 2009, Sant' Anna et al. 2014). Therefore, the search for markers of early renal damage that may predict the evolution of the disease is necessary, since serum creatinine, which has low sensitivity, is still the most commonly used marker in the clinical routine to detect this change in bitches with pyometra (De Loor et al. 2013, Pressler 2013).

In this context, the urine is easy to collect, and contains small amounts of protein; persistent proteinuria is related to a worse prognosis in patients with chronic kidney disease (Grauer $2005,2011)$. The study of proteinuria during the development of pyometra and the comparison of patients with different levels of renal damage can provide important information about the evolution of the disease, since a portion of patients remain proteinuria even after clinical recovery, being at elevated risk in the development of chronic renal failure.

The aim of this study was to evaluate whether urinary protein-to-creatinine (UPC) can detect renal injury in bitches with pyometra before the development of azotemia.

\section{MATERIALS AND METHODS}

Ethics statement. All the procedures in this study were submitted and approved by the animal ethics and experimentation committee.

Animals. The study included 44 bitches with pyometra and 12 bitches with no systemic symptomatology (control group). No breed was over-represented. The bitches with pyometra received clinical support and surgical treatment according to the clinical routine adopted for the treatment.

The diagnosis of the infection was based on patient history and clinical examination, and hematological exams and abdominal ultrasonography performed at the admission of the patients and confirmed during the surgical procedure.

The inclusion criterion for the pyometra group was diagnosis based on the tests used. Exclusion was based on suspected or confirmed concomitant disease.

The inclusion criteria for the control group were intact bitches, adult or elderly, who sought hospital care for surgeries, such as elective ovariohysterectomy $(\mathrm{OH})$, unilateral mastectomy due to single mammary neoplasia (less than $3 \mathrm{~cm}$ ), and periodontal treatment. Exclusion criteria for this group were when any systemic clinical abnormality was identified during anamnesis, general physical examination, blood count and plasma biochemistry (creatinine, alamino aminotransferase and glucose) performed at admission.

Bitches with pyometra were divided into two groups based on plasma creatinine levels and were considered azotemic when creatinine was greater than $1.7 \mathrm{mg} / \mathrm{dL}$. The pyometra non-azotemic group (NA) consisted of 29 bitches and the pyometra azotemic group (A) contained 15 animals. A third group was formed by 12 bitches in the control group (CG).

The mean age of the NA dogs was $8.0 \pm 4.0$ years, the A dogs was $10.0 \pm 3.0$ years and the CG was $9.5 \pm 3.0$ years. The mean weight of the NA dogs was $16.0 \mathrm{~kg}$, the A dogs was $14.5 \mathrm{~kg}$ and the CG was $11.0 \mathrm{~kg}$. Both age and weight were not significantly different between groups.

All patients underwent blood collection by puncture of the external jugular vein at admission. The sample was placed in a tube containing EDTA and sent to the laboratory for testing (complete blood count and creatinine, alanine aminotransferase and glucose dosage). The blood count result was used in the tabulation of the data and the biochemical results for the inclusion and exclusion criteria of the animals. Subsequently, all animals underwent a new blood collection after anesthetic induction with propofol. This sample was used to obtain the serum, after centrifugation for 5 minutes at $1,500 \mathrm{~g}$. The resulting supernatant was stored at $-20^{\circ} \mathrm{C}$ for evaluation of serum biochemistry.

Urine collection was performed by trans-surgical cystocentesis for bitches with pyometra or bitches of the CG group that passed through $\mathrm{OH}$. Ultrasound-guided cystocentesis was used in the other bitches of the CG. After urinalysis, the supernatant was stored at $-20^{\circ} \mathrm{C}$, which was used for UPC.

The UPC was performed only on urine samples without sediment. As an exclusion criterion, samples with more than five leukocytes and/or erythrocytes per field in the urinary sediment analysis were not included in the UPC assessment. The urinary density analysis was not performed in this study, since bitches with pyometra were given fluid therapy before the surgical procedure.

Hematology, biochemistry, urinalysis and UPC. The globular volume, hemoglobin, total red cell count and total leukocyte count were performed in an automated hematological analyzer. The differential leukocyte count was performed on a blood smear with Romanowisky-type staining (Fast Panoptic, Laborclin ${ }^{\circledR}$, Pinhais, 
Brazil) together with platelet estimation, which was averaged over five observed fields.

The determination of alanine aminotransferase (ALT), alkaline phosphatase (ALP), urea, creatinine and urinary creatinine were performed by the kinetic method. Proteins were determined by the biuret method for total protein, the colorimetric method using pyrogallol red for urinary protein and the colorimetric method for albumin, all with spectrophotometer reading (BS-120 Mindray ${ }^{\circledR}$, China). The UPC was calculated by dividing the urinary protein by the urinary creatinine (Thrall 2007).

The urinalysis was performed to evaluate the urinary sediment, which was obtained after centrifugation for 5 minutes at 1,500g and visualization of the sediment under a Neubauer camera microscopy. RBCs, leukocytes and bacteria were expressed in number per field.

Statistical analysis. The variables were analyzed using the statistical program Bioestat 5.0. Variables were tested for distribution by the Shapiro Wilk test. ANOVA followed by Tukey's test compared the variables with normal distribution (red blood cells, hematocrit and hemoglobin). Variables that did not present a normal distribution (albumin, total proteins, ALT, FA, urea, creatinine, urinary protein, urinary creatinine and UPC) were compared by the Kruskal Wallis test followed by the Dunn test. The level of significance was $\mathrm{p}<0,05$.

\section{RESULTS}

Hematological parameters were different between the groups of bitches with pyometra and the CG (Table 1). Among the hematological variables of the red series, the number of red blood cells, the hemoglobin level and the globular volume were smaller in the NA and A groups compared to the control group, but there was no difference between the NA and A groups. The median, total leukocytes, segmented neutrophils and band neutrophils were significantly higher in bitches with pyometra than in the CG. In addition, the median total and segmented leukocytes of group A were higher than in the NA group. The number of lymphocytes and platelets was not different between the groups, although the median number of platelets in group A was lower than the normal reference value for the canine species (Thrall 2007).
Among the biochemical parameters, serum albumin was significantly lower in dogs with pyometra than in the CG group, but there was no difference between the NA and A groups (Table 2).

The urinary creatinine concentration was significantly higher in the control group than in the NA group, but there was no difference between the NA and A groups. On the other hand, the concentration of the urinary protein of group A was higher than in the NA group and in the CG group (Table 3).

The median of the UPC in the control group was 0.23 , ranging from 0.14 to 0.49 . Therefore, all patients presented with a UPC within the reference values (Table 3). The NA group had a median UPC of 0.95 , ranging from 0.02 to 5.53 . In this group, 8/21 (38.1\%) presented a UPC <0.5, 4/21 (19\%), ranging from 0.5 to 1 , while $9 / 21$ (42.8\%) presented UPC $>1$.

\section{DISCUSSION}

Studies comparing the erythrogram parameters between bitches with pyometra and healthy bitches also have found similar findings (Hagman et al. 2006, Emanuelli et al. 2012). Bitches with pyometra developed mild to moderate anemia, since the mean globular volume of the NA and A groups were smaller than the bitches of the CG and lower than the reference values (Table 1). Anemia in canine pyometra is due to endotoxemia and sepsis secondary to uterine infection, which promotes decreased red blood cell survival and decreased bone marrow response to erythropoietin and is usually classified as moderate, aregenerative, normocytic and normochromic anemia (Pretzer 2008, Verstegen et al. 2008).

Leukocytosis in pyometra is characterized by an important regenerative deviation marked by the presence of rods in the circulation in response to infection, although in severe and/or chronic cases, leucopenia with degenerative deviation can be observed, indicating bone marrow depletion (Emanuelli et al. 2012, Hagman 2017). Acute renal disease may be due to decreased tissue perfusion associated with septic shock, and ischemic processes usually lead to tubular renal damage, as this part of the nephron is more metabolically active (Grauer 2005). Therefore, the association of more

Table 1. Erythrogram variables, expressed as the mean and standard deviation and leukocytes, expressed as median, minimum and maximum, and compared between the non-azotemic pyometra, azotemic pyometra and control groups

\begin{tabular}{|c|c|c|c|}
\hline Hematologic parameters & $\begin{array}{c}\text { Non-azotemic } \\
(\mathrm{n}=29)\end{array}$ & $\begin{array}{c}\text { Azotemic } \\
(\mathrm{n}=15)\end{array}$ & $\begin{array}{l}\text { Control } \\
(\mathrm{n}=12) \\
\end{array}$ \\
\hline Blood cells $\left(\mathrm{x} 10^{6}\right)$ & $5.05( \pm 1.90)^{\mathrm{A}}$ & $5.45( \pm 1.50)^{\mathrm{A}}$ & $7.27( \pm 1.09)^{\mathrm{B}}$ \\
\hline Hemoglobin (g/dl) & $10.7 \pm 4.2^{\mathrm{A}}$ & $11.6 \pm 3.1^{\mathrm{A}}$ & $16.1 \pm 2.1^{\mathrm{B}}$ \\
\hline Globular volume (\%) & $33.8 \pm 8.2^{\mathrm{A}}$ & $33.4 \pm 9.0^{\mathrm{A}}$ & $47.1 \pm 5.9^{\mathrm{B}}$ \\
\hline Total leukocytes $\left(\mathrm{m} / \mathrm{mm}^{3}\right)$ & $\begin{array}{c}26,400^{\mathrm{A}} \\
(9,100-75,600)\end{array}$ & $\begin{array}{c}43,500^{\mathrm{B}} \\
(18,700-101,300)\end{array}$ & $\begin{array}{c}8,650^{\mathrm{C}} \\
(5,500-16,660)\end{array}$ \\
\hline Segmented $\left(\mathrm{m} / \mathrm{mm}^{3}\right)$ & $\begin{array}{c}18,427^{\mathrm{A}} \\
(3,549-70.560)\end{array}$ & $\begin{array}{c}35,002^{\mathrm{B}} \\
(10,285-75,975)\end{array}$ & $\begin{array}{c}6,142^{\mathrm{C}} \\
(3,294-13,446)\end{array}$ \\
\hline Bands $\left(\mathrm{m} / \mathrm{mm}^{3}\right)$ & $\begin{array}{c}760^{\mathrm{A}} \\
(0-11,022)\end{array}$ & $\begin{array}{c}1.347^{\mathrm{A}} \\
(0-15,195)\end{array}$ & $\begin{array}{c}0^{\mathrm{B}} \\
(0-282)\end{array}$ \\
\hline Lymphocytes $\left(\mathrm{m} / \mathrm{mm}^{3}\right)$ & $\begin{array}{c}2,526 \\
(1,088-7,384)\end{array}$ & $\begin{array}{c}2,694 \\
(959-9,117)\end{array}$ & $\begin{array}{c}1,494 \\
(880-2,852)\end{array}$ \\
\hline Platelets $\left(\mathrm{m} / \mathrm{mm}^{3}\right)$ & $\begin{array}{c}225,000 \\
(28,000-990,000)\end{array}$ & $\begin{array}{c}166,000 \\
(39,000-897,000)\end{array}$ & $\begin{array}{c}250,000 \\
(102,000-382,000)\end{array}$ \\
\hline
\end{tabular}


Table 2. Biochemical variables expressed in median, minimal and maximal and compared between the non-azotemic, azotemic and control groups

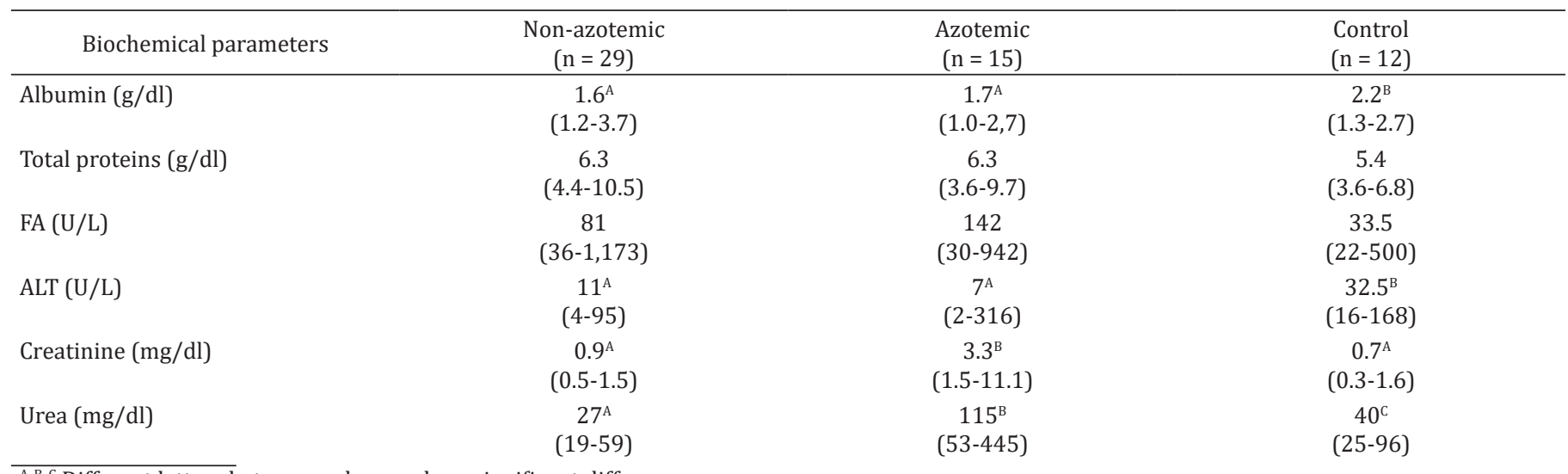

$\overline{\mathrm{A}, \mathrm{B}, \mathrm{C}}$ Different letters between columns show significant difference.

Table 3. Urinary parameters, expressed as median, minimum and maximum, and compared between the non-azotemic, azotemic, and control groups

\begin{tabular}{|c|c|c|c|}
\hline Urinary parameters & $\begin{array}{c}\text { Non-azotemic } \\
(\mathrm{n}=21)\end{array}$ & $\begin{array}{l}\text { Azotemic } \\
(\mathrm{n}=6)\end{array}$ & $\begin{array}{l}\text { Control } \\
(\mathrm{n}=11)\end{array}$ \\
\hline Urinary creatinine $(\mathrm{mg} / \mathrm{dl})$ & $\begin{array}{c}42.5^{\mathrm{A}} \\
(7.5-175)\end{array}$ & $\begin{array}{c}85^{\mathrm{AB}} \\
(27.5-217.5)\end{array}$ & $\begin{array}{c}145^{\mathrm{B}} \\
(40-345)\end{array}$ \\
\hline Urinary protein $(\mathrm{mg} / \mathrm{dl})$ & $\begin{array}{c}34.4^{\mathrm{A}} \\
(1.2-167.2)\end{array}$ & $\begin{array}{c}114.4^{\mathrm{B}} \\
(79,4-252,3)\end{array}$ & $\begin{array}{c}38.3^{\mathrm{A}} \\
(10.4-97.6)\end{array}$ \\
\hline UPC & $\begin{array}{c}0.95^{\mathrm{A}} \\
(0.02-5.53)\end{array}$ & $\begin{array}{c}1.67^{\mathrm{A}} \\
(0.52-3.02)\end{array}$ & $\begin{array}{c}0.23^{\mathrm{B}} \\
(0.14-0.49)\end{array}$ \\
\hline
\end{tabular}

$\overline{\mathrm{A}, \mathrm{B}, \mathrm{C}}$ Different letters between columns show significant difference.

severe leukocytosis in azotemic patients found in this study may indicate that renal hypo-perfusion secondary to sepsis is an important mechanism of worsening renal injury in bitches with pyometra.

Dogs with sepsis may develop thrombocytopenia due to the formation of platelet aggregates secondary to the action of lipopolysaccharides and interaction with neutrophils (Li \& Chan 2016), justifying the findings about lymphocytes and platelets.

Hypoalbuminemia in bitches is an inflammatory condition of infectious origin, mainly by Gram-negative bacteria, which may occur secondary to decreased liver production and/or increased vascular permeability, both due to the release of endotoxins (Greiner et al. 2008).

The difference found in creatinine and urea values between groups NA and A was expected, since the groups were formed based on creatinine values (Table 2). This is the differential of this study, with a significant number of bitches with non-azotemic and azotemic pyometra. Therefore, this allows the evaluation of UPC as a marker for early renal damage in bitches with pyometra.

Kidney damage caused during canine pyometra has long been credited to the formation of immune complexes in the circulation and subsequent deposition in the basement membrane of the glomerulus, causing glomerulonephritis (Johnston et al. 2001, Fieni 2006). However, this concept has been well-studied. Through the histopathological analysis of renal biopsies and the use of biomarkers of renal injury, studies have found that the renal compartment that is most affected in bitches with pyometra are tubular cells, and that the glomerular changes are similar to those found in healthy bitches of the same age group (Heiene et al. 2001, Zaragoza et al. 2004, Heiene et al. 2007, Maddens et al. 2010).

Serum creatinine and urinalysis are the methods used in clinical practice to detect and assess the extent of renal damage. However, serum creatinine increase and renal inability to concentrate urine only occurs after severe renal impairment. In addition to being less sensitive methods, they do not differentiate tubular and glomerular renal damage (Pressler 2013). On the other hand, proteinuria may indicate renal damage prior to the development of azotemia in dogs with chronic kidney disease and serves as an indicator to determine the severity of renal disease, which can be determined by UPC (Grauer 2005). In this study, the urinary creatinine concentration was significantly higher in the control group than in the NA group, but there was no difference between the NA and A groups. On the other hand, the concentration of the urinary protein of group A was higher than in the NA group and in the CG group (Table 3). These results have shown that proteinuria in bitches with pyometra and renal insufficiency is more evident, and reflects the severity of renal damage in group A. Renal proteinuria may be triggered by increased glomerular filtration of plasma proteins associated with intraglomerular hypertension, the 
presence of immunocomplexes, vascular inflammation in the glomerular capillaries, or structural defects in the basement membrane of the glomerulus. In addition, proteinuria may be tubular in origin, resulting in decreased tubular reabsorption of the plasma filtrate (De Loor et al. 2013).

Most of the time, dogs are considered to have proteinuria when the UPC $>0.5$. A UPC of 0.5 to 1 is usually associated with proteinuria of tubular origin and UPC $>1$ is associated with glomerular proteinuria (Grauer 2011, De Loor et al. 2013). The UPCs results show that bitches with pyometra without renal insufficiency have high UPC, most of them suggestive of glomerular lesion (42.8\%) and 19\% suggestive of tubular lesions. However, $38.1 \%$ were not considered proteinuric when we evaluated the UPC. This demonstrates the need for the use of more sensitive renal injury markers than the UPC for such patients, preventing false negative results.

In group $A$, the median UPC was 1.67 and ranged from 0.52 to 3.02. In this group $A$, none of the bitches presented UPC $<0.5,2 / 6(33.3 \%)$ presented UPC between 0.5 and 1 , and $4 / 6$ $(66.6 \%)$ presented UPC $>1$. These results demonstrate that when azotemic, bitches with pyometra show more evident proteinuria of glomerular origin.

Most bitches with pyometra of in both groups (NA and A) presented a UPC above the reference values for the species and significantly higher than the CG. Therefore, the UPC can be used to detect early renal damage in bitches with pyometra. Since UPC is a fast method and has lower cost, it should be used in the clinical routine for both early diagnosis of kidney injury in bitches with pyometra and in follow-up after clinical recovery from the infectious disease. As such, the bitches may become proteinuric and are more likely to develop chronic kidney failure if not treated correctly. Maddens et al. (2011) studied some markers of early renal damage in bitches with pyometra, and among them UPC. They also found a significant difference between the pyometra and control groups. The pyometra group was not separated in azotemic and non-azotemic dogs and it was not possible to evaluate if the UPC could detect renal damage before the development of azotemia.

\section{CONCLUSIONS}

The UPC can be used in bitches with pyometra to detect renal damage before the development of azotemia.

In addition, we suggest that bitches that had pyometra are followed up by urinalysis and UPC during the postoperative period, aiming at the diagnosis of permanent renal lesions.

As such, these patients will be treated properly prior to the development of azotemia, increasing the survival and quality of life of patients.

\section{REFERENCES}

Bassessar V., Verma Y. \& Swamy M. 2013. Antibiogram of bacterial species isolated from canine pyometra. Vet. World 6(8):546-549. <http://dx.doi. org/10.5455/vetworld.2013.546-549>

De Loor J., Daminet S., Smets P., Maddens B. \& Meyer E. 2013. Urinary biomarkers for acute kidney injury in dogs. J. Vet. Intern. Med. 27(5):9981010. <http://dx.doi.org/10.1111/jvim.12155><PMid:23952327>

Emanuelli M.P., Martins D.B., Wolkmer P., Antoniazzi A.Q., Emanuelli T., de Vargas A.C. \& dos Anjos Lopes S.T. 2012. Complete blood count, total plasma protein, neutrophil oxidative metabolism, and lipid peroxidation in female dogs with pyometra associated with Escherichia coli. Comp. Clin. Pathol. 21(3):309-313. <http://dx.doi.org/10.1007/s00580-010-1097-z.

Fieni F. 2006. Patologia de los ovários y el útero, p.75-89. In: Wanke M.M. \& Gobello C. Reproduccion en Caninos y Felinos Domesticos. Ed. InterMédica, Buenos Aires.

Grauer G.F. 2005. Early detection of renal damage and disease in dogs and cats. Vet. Clin. N. Am., Small. Anim. Pract. 35(3):581-596. <PMid:15833560>

Grauer G.F. 2011. Proteinuria: measurement and interpretation. Topics Companion Anim. Med. 26(3):121-127. <http://dx.doi.org/10.1053/j. tcam.2011.04.002 ><PMid:21782142>

Greiner M., Wolf G. \& Hartmann K. 2008. A retrospective study of the clinical presentation of 140 dogs and 39 cats with bacteraemia. J. Small Anim. Pract. 49(8):378-383. <http://dx.doi.org/10.1111/j.1748-5827.2008.00546.x> $<$ PMid:18422500>

Hagman R. 2004. New aspects of canine pyometra: studies on epidemiology and pathogenesis. Doctoral Dissertation, Swedish University of Agricultural Sciences, Uppsala. 55p.

Hagman R. 2017. Canine pyometra: what is new? Reprod. Domest. Anim. 52(Suppl.2):288-292.<PMid:27807901>

Hagman R. \& Kuhn I. 2002. Escherichia coli strains isolated from the uterus and urinary bladder of bitches suffering from pyometra: Comparison by restriction enzyme digestion and pulsed-field gel electrophoresis. Vet. Microbiol. 84(1/2):143-153. <http://dx.doi.org/10.1016/S03781135(01)00449-7><PMid:11731167>

Hagman R., Kindahl H., Fransson B.A., Bergstrom A., Holst B.S. \& Lagerstedt A.S. 2006. Differentiation between pyometra and cystic endometrial hyperplasia/mucometra in bitches by prostaglandin F $2 \alpha$ metabolite analysis. Theriogenology 66(2):198-206. <http://dx.doi.org/10.1016/j. theriogenology.2005.11.002><PMid:16375957>

Heiene R., Kristiansen V., Teige J. \& Jansen J.H. 2007. Renal histomorphology in dogs with pyometra and control dogs, and long term clinical outcome with respect to signs of kidney disease. Acta Vet. Scand. 49(1):13. <http:// dx.doi.org/10.1186/1751-0147-49-13><PMid:17480218>

Heiene R., Moe L. \& Molmen G. 2001. Calculation of urinary enzyme excretion, with renal structure and function in dogs with pyometra. Res. Vet. Sci. 70(2):129-137. <http://dx.doi.org/10.1053/rvsc.2000.0451> <PMid:11356092>

Johnston S.D., Kustritz M.V.R. \& Olson P.N.S. 2001. Canine and Feline Theriogenology. W.B. Saunders, Philadelphia. 592p.

Kuplulu S., Vural M.R., Demirel A., Polat M. \& Akçay A. 2009. The comparative evaluation of serum biochemical, haematological, bacteriological and clinical findings of dead and recovered bitches with pyometra in the postoperative process. Acta Vet. 59(2/3):193-204.

Li R.H.L. \& Chan D.L. 2016. Evaluation of platelet function using multiple electrode platelet aggregometry in dogs with septic peritonitis. J. Vet. Emerg. Crit. Care, San Antonio, 26(5):630-638. <PMid:27428542>

Maddens B., Daminet S., Smets P. \& Meyer E. 2010. Escherichia coli pyometra induces transient glomerular and tubular dysfunction in dogs. J. Vet. Intern. Med. 24(6):1263-1270.<http://dx.doi.org/10.1111/j.1939-1676.2010.0603. $\mathrm{x}><$ PMid:21039862>

Maddens B., Heiene R., Smets P., Svensson M., Aresu L., van der Lugt J., Daminet S. \& Meyer E. 2011. Evaluation of kidney injury in dogs with pyometra based on proteinuria, renal histomorphology, and urinary biomarkers. J. Vet. Intern. Med. 25(5):1075-1083.<http://dx.doi.org/10.1111/j.1939-1676.2011.0772. $\mathrm{x}><$ PMid:21848947>.

Pressler B.M. 2013. Clinical approach to advanced renal function testing in dogs and cats. Vet. Clin. N. Am., Small Anim. Pract. 43(6):1193-1208. <http://dx.doi.org/10.1016/j.cvsm.2013.07.011> <PMid:24144085> 
Pretzer S.D. 2008. Clinical presentation of canine pyometra and mucometra: a review. Theriogenology 70(3):359-363. <http://dx.doi.org/10.1016/j. theriogenology.2008.04.028><PMid:18513791>

Sant'Anna M.C., Giordano L.G.P., Flaiban K.K.M.C., Muller E.E. \& Martins M.I.M. 2014. Prognostic markers of canine pyometra. Arq. Bras. Med. Vet. Zootec. 66(6):1711-1717. <http://dx.doi.org/10.1590/1678-6859>

Thrall M.A. 2007. Hematologia e Bioquímica Clínica Veterinária. Roca, São Paulo. 592p.
Verstegen J., Dhaliwal G. \& Verstegen-Onclin K. 2008. Mucometra, cystic endometrial hyperplasia, and pyometra in the bitch: advances in treatment and assessment of future reproductive success. Theriogenology 70(3):364374. <http://dx.doi.org/10.1016/j.theriogenology.2008.04.036>. $<$ PMid:18501959>.

Zaragoza C., Barrera R., Centeno F., Tapia J.A. \& Mane M.C. 2004. Canine pyometra: a study of the urinary proteins by SDS-PAGE and Western blot. Theriogenology 61(7/8):1259-1272. <http://dx.doi.org/10.1016/j. theriogenology.2003.07.019><PMid:15036960> 